\title{
Pesan Dakwah dalam Puisi Gus Mus
}

\author{
Lina Ulistiani ${ }^{1 *}$, Dindin Solahudin ${ }^{2}$, Aang Ridwan $^{1}$ \\ ${ }^{1}$ Jurusan Komunikasi dan Penyiaran Islam, Fakultas Dakwah dan Komunikasi, \\ UIN Sunan Gunung Djati, Bandung \\ 2Jurusan Pengembangan Masyarakat Islam, Fakultas Dakwah dan Komunikasi, \\ UIN Sunan Gunung Djati, Bandung \\ *Email : linaomet02@gmail.com
}

\begin{abstract}
Da'wah by poetry is only a few poets who have originality. KH. Mustofa Bisri or well known as Gus Mus, is a religious poet. Therefore, with the poetry present in the anthology of Tadarus, we will examine a message of da'wah in it. The method to be used in this research is descriptive method. Because it aims to provide exposure and explanation of the messages contained in a poem. The analysis to be used is semantic analysis, the analysis of the meaning proposed by Rudolf Carnap. This research is carried out by taking steps: determining the location of research, determining the research method, determining the data type, determining the data source, determining the data collection techniques and determining the technique of data analysis. The results showed that in the Anthology of Tadarus poetry, has the contents of messages, namely messages of worship, aqidah messages, and morals messages. While the characteristics of the message of da'wah contained in the Anthology of Tadarus Poetry is to contain elements of truth, bringing the message of peace, not against the universal values, making it easy for the recipient of the message.
\end{abstract}

Keywords: da'wah message; Gus Mus, poetry anthology; semantics

\begin{abstract}
ABSTRAK
Berdakwah dengan cara puisi tentu hanya beberapa penyair yang mempunyai kekhas-an tersebut. KH. Mustofa Bisri atau dikenal sebagai Gus Mus, beliau merupakan penyair yang bisa dibilang religius. Oleh karena itu, dengan puisi yang ada dalam antologi Tadarus inilah, akan diteliti sebuah pesan-pesan dakwah di dalamnya. Metode yang akan digunakan dalam penelitia ini adalah metode deskriptif. Karena bertujuan untuk memberikan pemaparan dan penjelasan tentang pesan yang terkandung dalam sebuah puisi. Analisis yang akan digunakan adalah analisis semantik, yakni analisis tentang makna yang dikemukakan oleh Rudolf Carnap. Penelitian ini dilakukan dengan menempuh langkah-langkah: menentukan lokasi penelitian, menentukan metode penelitian, menentukan jenis data, menentukan sumber data, menentukan teknik pengumpulan data dan menentukan teknik analisis data. Hasil penelitian menunjukan bahwa dalam Antologi Puisi Tadarus ini, mempunyai isi pesan-pesan, yakni pesan-pesan ibadah,
\end{abstract}


pesan-pesan aqidah, dan pesan-pesan akhlaq. Sedangkan karakteristik pesan dakwah yang terkandung dalam Antologi Puisi Tadarus ini adalah mengandung unsur kebenaran, membawa pesan perdamaian, tidak bertentangan dengan nilainilai universal, memberikan kemudahan bagi penerima pesan.

Kata Kunci : pesan dakwah; antologi puisi; Gus Mus; semantik

\section{PENDAHULUAN}

Dakwah secara umum dapat dibagi menjadi dua: definisi menurut bahasa (lughawi) dan menurut istilah. Dari segi bahasa atau definisi bahasa kata dakwah berasal dari bahasa Arab dari kata “dakwah"yang merupakan isim masdar, berasal dari fi'il (kata kerja) yaitu da'a yang artinya memanggil, mengajak atau menyeru. Sedangkan dakwah menurut istilah mencakup arti dakwah dalam arti terbatas dan dalam arti luas.

Dalam arti terbatas, dakwah yaitu penyampaian Islam kepada manusia, baik secara lisan, tulisan maupun lukisan (panggilan, seruan dan ajakan kepada manusia terhadap Islam. Sedangkan dalam arti luas, dakwah adalah penjabaran, penerjemahan dan pelaksanaan Islam dalam peri-kehidupan dan penghidupan manusia termasuk di dalamnya bidang pendidikan, politik, ekonomi, sosial, ilmu pengetahuan, kesenian, kekeluargaan dan sebagainya (Tajiri, Academic Journal for Homiletic Studies: 2016).

Pesan dakwah adalah beberapa macam informasi dari berbagai sumber dalam sebuah dakwah atau seruan yang bersifat kepada ajakan positif mengikuti petunjuk Allah dan Rasul-Nya. Pada dasarnya, setiap pesan dapat dijadikan sebagai pesan dakwah selama pesan tersebut tidak bertentangan dengan ajaran Islam.

Pesan disampaikan dengan tepat tentunya melalui media yang tepat, bahasa yang dimengerti, sesuai dengan maksud dan kata-kata yang sederhana, serta tujuan pesan tersebut dapat tersampaikan dan dapat pula dicerna oleh komunikan.

Adapun pengertian yang lainnya pesan merupakan keseluruhan daripada apa yang di sampaikan oleh komunikator. Pesan seharusnya mempunyai inti pesan (tema) sebagai pengarah didalam usaha mencoba mengubah sikap dan tingkah laku komunikan. Pesan dapat disampaikan secara panjang lebar, namun yang perlu diperhatikan dan diarahkan kepada tujuan akhir dari komunikasi (A. W. Widjaja, 1986: 14-12).

Isi pesan dalam dakwah merupakan bahan atau materi yang dipilih dan ditentukan oleh komunikator untuk mengkomunikasikan segala sesuatu tentang dakwah. Isi pesan apapun yang utama hadir melalui pikiran, ada kalanya juga perasaan, tetapi hanya merupakan faktor pengaruh saja. Isi pesan yang baik, perlu diketahui sampai atau tidaknya kepada para komunikan. Berdasarkan temanya, isi pesan dalam dakwah tidak berbeda dengan pokok-pokok ajaran Islam. Asmuni Syukir (1983: 60), mengatakan bahwa secara global dapat dikatakan bahwa pesan dakwah dapat dibagi menjadi tiga bagian. Pertama, ibadah yakni taat kepada Allah 
dengan melaksanakan perintah-Nya melalui lisan para Rasul. Kedua, Aqidah yang meliputi iman kepada Allah, iman kepada malaikat-malaikat Allah, iman kepada Nabi dan Rasul, iman kepada kitabb-kitab Allah, dan iman kepada Hari Akhir dan Iman kepada Qadha dan Qadhar. Ketiga, Akhlak, yang berkaitan dengan masalah tabiat atau kondisi temperatur batin yang mempengaruhi perilaku manusia.

Didalam buku Filsafat Dakwah karya Abdul Basit (2013: 142-146), pesan dakwah tentu memiliki sebuah ciri atau karakteristik yang tentunya berbeda dengan karakteristik pesan yang bukan dakwah.

Karakteristik pertama dalam pesan dakwah adalah adanya kebenaran dalam setiap pesan yang disampaikan. Berbeda dengan komunikasi, dimana setiap prosesnya bisa mengandung unsur yang tidak benar atau negatif.

Kebenaran yang dimaksud dalam pesan dakwah adalah kebenaran yang bersumber dari Allah SWT, sebagaimana dinyatakan dalam firman-Nya "kebenaran itu datangnya dari Tuhanmu, sebab itu jangan jangan sekali-kali engkau ragu". Kebenaran yang bersumber dari Allah tersebut berwujud dalam bentuk rangkaian ayat-ayat yang terdapat dalam Al-Qur'an. Jadi Al-Qur'an merupakan sumber kebenaran yang mutlakyang perlu disampaikan oleh da'i kepada manusia.

Dua, membawa pesan perdamaian. Perdamaian merupakan sebuah unsur penting yang harus dikembangkan dalam penyampaian pesan dakwah. Menurut Hasan Hanafi (2001: 129), perdamaian bukan sekedar hukum internasional antara negara-negara adidaya. Perdamaian berawal dari individu, kemudian berkembang ke keluarga dan ke kehidupan sosial.

Tiga, tidak bertentangan dengan nilai-nilai universal. Pesan dakwah hendaknya disampaikan dalam konteks lokalitas dari mad'u yang menerima pesan. Dengan cara tersebut, pesan dakwah akan mudah diterima oleh masyarakat karena sesuai dengan kebutuhan dan kegiatan masyarakat. Persoalan yang muncul kepermukaan ketika ajaran Islam diyakini sebagai ajaran yang bersumber dari Arab sehingga lokalitas "ke-Arab-an" menjadi sesuatu yang dianggap universal dan mesti diikuti oleh masyarakat di luar Arab. Seakan-akan Islam tidak meperhatikan perbedaan wilayah dan latar belakang masyarakat yang menjadi objek dakwah. Dalam hal ini kita perlu membedakan antara sumber dengan proses penyampaian dan pemaknaan pesan dakwah.

Empat, memberikan kemudahan bagi penerima pesan. Memberikan kemudahan dalam menyampaikan pesan dakwah merupakan sesuatu yang dianjurkan dan bahkan menjadi tujuan syariat Islam, sebagaimana dijelaskan dalam Al-Qur'an "Allah menghendaki kemudahan bagimu dan tidak menghendaki kemungkaran bagimu".

Memudahkan dalam pesan dakwah tidak diartikan memilih-milih hukum yang ringan-ringan saja dari berbagai pendapatulama fikih (melakukan taklifi). Memudahkan yang dimaksud sebagai kemudahan dalam pengalaman ajaran agama yang tidak bertentangan dengan nash-nash dan kaidah syariat Islam.

Lima, mengapresiasi adanya perbedaan. Ada pengalaman menarik ketika ada seorang da'i menyampaikan pesan-pesan dakwahnya dengan lantang dan 
penuh semangat. Materi yang disampaikan berkisar pada praktik keberagaman yang biasa dilakukan oleh kalangan nahdliyin. Da’i tersebut kurang mengenal mad'u dan kurang membaca situasi dimana jamaah tersebut berada. Ternyata jamaah yang diajak umumnya kalangan Muhammadiyah. Akhirnya, apa yang disampaikan oleh da'i tersebut kurang mendapatkan tanggapan positif dari para jamaah. Mereka hanya diam dan terkadang mengabaikan apa yang disampaikan oleh da'i tersebut.

Pada dasarnya, setiap pesan dapat dijadikan sebagai pesan dakwah selama pesan tersebut tidak bertentangan dengan ajaran Islam. Salah satunya pesan dakwah melalui karya sastra puisi. Puisi merupakan jenis karya sastra yang mengungkapkan penggambaran oleh penyair secara kreatif dan imajinatif yang disusun dengan bahasa-bahasa yang indah.

Pesan dakwah atau materi dakwah adalah isi dakwah yang di sampaikan da'i kepada mad'u yang bersumber dari agama Islam (Jamaludin Kafie, 1997: 35).

Secara global dapat dikatakan bahwa materi dakwah dapat diklasifikasikan menjadi tiga bagian pokok, yaitu: pesan-pesan ibadah, pesan-pesan aqidah, dan pesan-pesan akhlaq (Asmuni Syukir, 1983: 60).

Menurut Ali aziz dalam bukunya Ilmu Dakwah Edisi Revisi, dijelaskan bahwa jenis pesan dakwah pada garis besarnya terbagi menjadi dua, yaitu pesan utama (al-qur'an dan hadits) tetapi ada pula pesan tambahan atau penunjang (selain al-qur'an dan hadits). Adapaun jenis-jenis pesan dakwah antara lain sebagai berikut: ayat-ayat al-qur'an, Hadits Nabi, pendapat para sahabat nabi Muhammad SAW, pendapat para ulama, hasil penelitian ilmiah, kisah dan pengalaman teladan, berita dan peristiwa (Aziz, 2014: 320).

Membedakan pesan dakwah dari pesan pesan komunikasi atau pesan yang lainnya, maka diperlukan adanya karakteristik pesan dakwah sebagai berikut: mengandung unsur kebenaran, membawa pesan perdamaian, tidak bertentangan dengan nilai-nilai universal, memberikan kemudahan bagi penerima pesan, dan mengapresiasi adanya perbedaan (Basit, 2013: 142-146).

Secara bahasa puisi artinya "pembangun, pembentuk, pembuat". Menurut isliah puisi memiliki arti "membangun, dan menyair". Puisi berubah saat ini menjadi seni sastra yang kalimat tersusun menurut syarat dengan menggunakan irama, kata-kata kiasan. Sedangkan menurut Sujiman dalam buku Soepandi memahami puisi merupakan ragam sastra bahasanya terkait oleh rima, matra (Sopandi, 2010: 2-3).

Puisi sebagai salah satu sebuah karya seni sastra yang dapat dikaji dari bermacam-macam aspeknya. Puisi itu adalah struktur yang tersusun dari bermacam-macam unsur dan sarana-sarana kepuitisan. Dapat pula puisi dikaji jenis-jenis atau ragam-ragamnya, mengingat bahwa ada beragam-ragam puisi. Begitu juga, puisi dapat dikaji dari sudut kesejarahannya, mengingat bahwa sepanjang sejarahnya, dari waktu ke waktu puisi selalu ditulis dan dibaca orang (Djoko P, 2014: 12).

Sepanjang zaman puisi selalu mengalami perubahan, perkembangan. Hal ini 
mengingat hakikatnya sebagai karya seni yang selalu terjadi ketegangan antara konvensi dan pembaharuan (inovasi) (Teeuw, 1980: 12).

Sebagai sebuah genre, puisi berbeda dari novel, drama atau cerita pendek. Perbedaannya terletak pada kepadatan komposisi dengan konvensi yang ketat, sehingga puisi tidak memberi ruang gerak yang longgar kepada penyair dalam berkreasi secara bebas. Wajar kalau puisi dikatakan sebagai the most condensed and concentrated from of literatur (Perrine, 1974: 559).

Yang maksudnya adalah puisi merupakan bentuk sastra yang paling padat dan terkonsentrasi. Kepadatan komposisi tersebut ditandai dengan pemakaian sedikit kata, namun mengungkapkan lebih banyak hal. Sebab itu puisi dapat didefinisikan sebagai sejenis bahasa yang mengatakan lebih intensif daripada yang dikatakan oleh bahasa harian (Perrine, 1974: 553).

Definisi diatas menyatakan secara implisit bahwa puisi sebagai bentuk sastra menggunakan bahasa sebagai media pengungkapannya. Hanya saja bahasa puisi memiliki ciri-ciri tersendiri yakni kemampuannya mengungkap lebih internsif dan lebih banyak ketimbang kemampuan yang dimiliki oleh bahasa biasa yang cenderung besifat informatif praktis. Oleh sebab itu, pesan yang disampaikan bersifat jelas dan tidak mengandung dimensi ambigu.

Dakwah bisa dilakukan oleh umat Islam melalui sebuah media. Media merupakan segala hal yang membantu juru dakwah dalam menyampaikan dakwahnya secara efisien. (Asmuni Syukir, 1983: 163). Media berasal dari bahasa latin yaitu medius yang secara harfiah berarti perantara, tengah atau pengantar. Dalam bahasa inggris media bentuk dari medium yang berarti tengah, antara, ratarata. (Aziz, 2004: 403). Adapun yang dimaksud dengan media dakwah adalah alat yang dipergunakan untuk menyampaikan materi dakwah kepada mad'u (Saputra, 2012: 288).

Wilbur Schraman mendefinisikan media sebagai teknologi informasi yang dapat digunakan dalam pengajaran. Secara spesifik, yang dimaksud dengan media adalah alat-alat fisik yang menjelaskan isi pesan atau pengajaran, seperti buku, film, video, kaset, slide, dan sebagainya. Pada zaman modern seperti sekarang ini, seperti televisi, video, kaset rekaman, majalah dan surat kabar.

Media adalah segala sesuatu yang dapat dijadikan sebagai alat perantara untuk mencapai satu tujuan tertentu. Sedangkan dakwah adalah segala sesuatu yang dapat dipergunakan sebagai alat untuk mencapai tujuan dakwah yang telah ditentukan, media dakwah ini dapat berupa barang atau alat, orang, tempat, kondisi tertentu dan sebagainya.

Media dakwah menurut Samsul Munir dalam bukunya "Ilmu Dakwah" dibagi menjadi dua, yaitu: non media massa yakni manusia dan benda. media massa, meliputi media massa manusia: pertemuan, rapat umum, seminar, sekolah, dan lain-lain. Media massa benda: spanduk, buku, selebaran, poster, folder, dan lain-lain. Dan media massa periodik cetak dan elektronik: visual, audio, dan audio visual.

Media dakwah menurut Hamza Ya'kub membagi media menjadi lima macam: lisan yakni dakwah secara langsung melalui perkataan seperti ceramah, 
khutbah, pidato, bimbingan, dan lain-lain. Tulisan yaitu bentuk tulisan yang dapat berupa novel, majalah, koran, spanduk, dan lainya.

Pemaparan di atas dijelaskan bahwa puisi merupakan sebuah media untuk berdakwah. Tentunya dapat dikatakan sebuah media berdakwah, jika puisi tersebut memiliki makna-makna kandungan kata yang berunsurkan pesan dakwah, dengan begitu puisi dapat dikatakan sebagai media untuk berdakwah (Munir dan Ilaihi, 2009: 32).

Ahmadun Y. Herpanda mengatakan bahwa sastra pada periode yang disebut kontemporer ini, asyik bermain dengan idom-idom dunia industri, dunia hiburan, dan dunia urban yang dianggap sebagai idiom postmodern sehingga puisi Indonesia hanya berisi permainan kata-kata dan kehilangan kekuatan pencerahnya (Salahudin, 1993: 22-42).

Media merupakan segala sesuatu yang dipergunakan dan bisa menunjang dalam berlangsungnya pesan dari komunikan (da'i) kepada khalayak. Atau dengan kata lain bahwa segala sesuatu yang dapat menjadi penunjang atau alat dalam proses dakwah yang berfungsi mengefektifkan penyampaian ide (pesan) dari komunikator (da'i) kepada komunikan (khalayak).

Pada zaman sekarang ini yang penuh dengan kecanggihan media, seperti televisi, kaset, radio, surat kabar, majalah dan lain-lain. Maka dari itu, seorang da'i harus bisa memilih media yang efektif untuk mencapai tujuan dakwah. Tentunya dengan memilih yang tepat atau dengan prinsip-prinsip media.

Dakwah melalui media puisi tentu tidak kalah efektif dengan media yang lain. karena puisi merupakan sebuah sarana yang penyampaian dakwahnya tidak membedakan golongan. Puisi juga bisa memberikan pesan-pesan yang tidak dapat terlupakan bagi pembacanya, apalagi bagi seorang penyair. Karena puisi memiliki makna pada kehidupan-kehidupan yang sedang diamati oleh sang penyair.

Perkembangan puisi di Indonesia tidak bisa lepas dari peran penyair, baik yang berasal dari lingkungan umum maupun dari pesantren. Salah satu puisi tersebut dapat dicontohkan dalam karya-karyanya KH. A. Mustofa Bisri atau sering dipanggil dengan sebutan Gus Mus. Puisi merupakan sebuah media yang baik juga untuk berdakwah dikalangan penyair. Bersyair yang baik menurut Allah adalah bersyair dengan catatan dia beriman, beramal baik, banyak mengingat Allah dan melakukan pembelaan ketika di zalimi, bukan penyair-penyair yang diikuti oleh orang-orang yang sesat yakni yang bersyair atau yang berbicara sastra dengan berdusta.

Dari latar belakang masalah tersebut dapat dirumuskan beberapa masalah dengan rumusan masalah: Bagaimana isi pesan dakwah dalam Antologi Puisi Tadarus? Bagaimana karakter pesan dakwah dalam Antologi Puisi?. Metode yang digunakan dalam penelitian ini adalah dengan kualitatif deskriptif berdasarkan analisa semantik atau makna. 


\section{HASIL DAN PEMBAHASAN}

Hasil penelitian dan pembahasan berdasarkan analisis semantik dalam antologi puisi dalam penelitian. Hasil yang telah diperoleh, kemudian disesuaikan dengan rumusan masalah dan tujuan penelitian.

Antologi puisi Tadarus karya Gus Mus, merupakan sebuah kumpulan puisipuisi setelah Ohoy. Dalam penelitian ini, akan dilakukan analisis dari Rudolf Carnap dari beberapa puisi, agar bisa terlihat apa makna yang terkandung dalam isi pesan dan karakter pesan.

Asmuni Syukir (1983: 60), mengatakan bahwa secara global dapat dikatakan bahwa pesan dakwah dapat dibagi menjadi tiga bagian yakni ibadah, aqidah, dan akhlaq.

Isi Pesan Dakwah dalam Antologi Puisi Tadaru.

Puisi 1, Tadarus

Bismillaabirrahmaanirrabiem. Berhenti darahku menyimak firmanMu

Kalimat diatas merupakan makna sebenarnya, karena tidak ada kata-kata yang tidak dimengerti. Kata ini memiliki sebuah isi makna yang dimana seseorang sedang mendengarkan ucapan atau firman Allah SWT sehingga ia terkejut hingga darahnya terhenti karena keterkejutannya.

Idzaa Zulzilatil-ardlu zilzaalahaa Wa akhrajatil-ardlu atsqaalahaa Waqaalalinsaanu maa labaa (Ketika bumi diguncang dengan dahsyatnya Dan bumi memuntahkan isi perutnya Dan manusia bertanya-tanya: Bumi ini kenapa?)

Isi makna dalam kalimat ini yakni, saat bumi di robohkan, di hancurkan dengan guncangan yang amat menakutkan. Bumi diguncangkan hebat yang menjadikan segala apa yang ada di dalam bumi terbongkar dan keluar. Manusia bertanya-tanya, menanyakan ada apa dengan bumi, sehingga terjadi seperti ini?.

Yaumaidzin tuhadditsu akbbaarahaa Bianna Rabbaka aubaa labaacYaumaidzin yashdurun-naasu asytaatan Liyurau a'maalahum. (Ketika itu bumi mengisahkan kisahkisahnya Karena Tuhanmu mengilhaminya Ketika itu manusia tumpah terpisahpisah 'Tuk diperlihatkan perbuatan-perbuatan mereka)

Kalimat diatas memiliki isi makna ketika, saat itu bumi menceritakan peristiwa-peristiwa yang akan terjadi pada suatu hari. bahwa pada saat bumi sudah digoncangkan dan mengeluarkan seluruh isi bumi, pada saat itu pun manusia keluar dari tempatnya akan berpisah-pisah, terpencar dan akan diperlihatkan karena perbuatan-perbuatan manusia sendiri.

Faman ya'mal mitsqaala dzarratin khairan yarah Waman ya'mal mitsqaala dzarratin syarran yarah. (Maka siapa yang berbuat sedzarrah kebaikan pun akan melihatnya Dan siapa yang berbuat sedzarrah kejahatan pun akan melihatnya).

Isi makna dari kalimat di atas yakni barangsiapa sekicil apapun berbuat sebuah kebaikan, maka akan terlihat nantinya. Begitupun sebaliknya berbuat sekicil apapun kejahatan atau kemaksiatan, kesalahan akan terlihat balasannya nanti.

Ya Tuhan, akulah insan yang bertanya-tanya ataukah aku mukmin yang sudah tahu jawabannya? Kulihat setetes diriku dalam muntahan isi bumi. Aduhai, 
akan kemanakah kiranya bergulir? Diantara tumpukkan maksiat yang kutimbun saat demi saat. Akankah kulihat sedzarrah saja. Kebaikan yang pernah kubuat?. Nafasku memburu firmanMu.

Isi makna bahwa seorang hamba atau manusia bertanya-tanya tentang kejadian apakah itu. Dia bingung apakah dia seorang manusia yang beriman yang lupa bahwa akan ada kejadian yang akan terjadi seperti yang di katakan Allah dalam sebuah firman. Mereaka bertanya akan kemanakah dia bergerak? Dia sadar bahwa dosa-dosa yang telah dia lakukan menumpuk dari waktu ke waktu. Mereka merenungkan dirinya karena sekecil kebaikan yang ia perbuat akankah terlihat.

Dengan asma Allah Yang Maha Pengasih Penyayang

Kalimat diatas merupakan sebuah makna yang sebenarnya. Isi makna yang terkandung dalam kalimat tersebut yakni dengan menyebut nama Allah yang maha kasih dan maha sayang dari apapun.

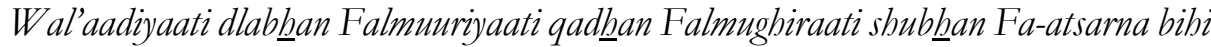
naq'an Fawasathna bihi jam'an. (Demi yang sama berpacu berdengkusan. Yang sama mencetuskan api berdenyaran. Yang pagi-pagi melancarkan serbuan Menerbangkan debu berhamburan Dan menembusnya ke tengah-tengah pasukan lawan).

Kalimat diatas merupakan kalimat yang mengandung makna sebenarnya. Isi dari makna kalimat tersbut yakni untuk kita yang sama-sama berlari kencangkencang dengan menghembuskan napas sekuat-kuatnya dari hidung. dimana ketika saat pagi membuat lancar, menjalankan serangan. Membiarkan debu berserakan dimana-mana.

Innal-insaana liRabbihi lakanuud Wainnabu 'alaa dzalika lasyahied Wainnabu libubbil-khairi lasyadied (Sungguh manusia itu kepada Tuhannya sangat tidak tahu berterima kasih Sungguh manusia itu sendiri tentang itu menjadi saksi Dan sungguh manusia itu sayangnya kepada harta Luar biasa).

Kalimat diatas adalah kalimat yang mempunyai makna yang sebenarnya. Yang memiliki sebuah isi makna yakni menggambarkan sebuah kebenaran bahwa manusia tidak pernah berterimakasih kepada Allah. Manusia sendirilah yang akan mengetahui sendiri peristiwa atau kejadian. Memanglah tidak dapat di pungkiri manusia di dunia memang tamak, serakah kepada harta, oleh karena itu mereka lupa dengan Tuhan.

Afalaa ya'lamu idzaa bu'tsira maa fil qubur Wabushshila maa fish-shuduur Inna Rabbabum bibim yaumaidzin lakhabier (Tidaklah manusia itu tahu saat isi kubur dihamburkan Saat isi dada ditumpahkan? Sungguh Tuhan mereka Terhadap mereka saat itu tahu belaka!).

Kalimat di atas memiliki sebuah makna, bahwa manusia tidak akan tahu kapan waktunya kiamat atau segala yang berada di dalam bumi di keluarkan dengan dahsyat hingga lalu di tumpahkan kepada makhluk yang ada di bumi. Dan hanya Allah yang tahu kapan hari itu akan terjadi.

Ya Tuhan, kemana gerangan butir drbu ini 'kan Menghambur? Adakah secercah syukur menempel Ketika isi dada dimuntahkan Ketika semua 
kesayangan dan andalan entah kemana?

Kalimat diatas menggambarkan bahwa manusia pada saat itu mulai bertanya, akan kemanakah dia akan berlari. Disaat manusia yang kita percayai, keluarga yang di kenal entah pada kemana, karena akan terpisah-pisah.

"Meremang bulu romaku diguncang firmanMu" Kalimat diatas yang terkandung dalam kalimat di atas yakni mendengar ayat-ayat Allah yakni AlQur'an seketika merasa seram.

Bismillaahirrabmaanirrabiem Al-Qaariah Mal-qaariah Wamaa adraaka malqaari'ah (Penggetar hati Apakah penggetar hati itu? Tahu kau apa itu penggetar hati?).

Isi makna yang terdapat dalam kalimat tersebut ialah semua orang menjadi kacau-balau. Apa yang menjadi kacau-balau itu dan sekli lagi apa yang kacau-balau. Saking dahsyatnya kata-kata berulang.

Resah sukmaku dirasuki firmanMu.

Yang mempunyai isi makna bahwa aku merasa gelisah meresapkan ayat-ayat Allah tersebut.

Yauma yakuunun-naasu kal-faraasyil-mabtsuuts Waltakuunul-jibaalu kal-ibnilmanfuusy (Itulah manusia bagaikan belalang bertebaran dan gunung-gunung bagaikan bulu dihambur-terbangkan).

Isi makna yang terdapat dalam kalimat tersebut ialah penggetar hati itu adalah hari kiamat. Dimana pada hari tersebut manusia akan bertebaran karena tidak dapat mengelak akan kejadian itu, saking luar biasanya peristiwa tersebut dan gunung yang merupakan paku bumi kan mengeluarkan isinya hingga tak ada lagi gunung karena telah berhamburan.

Menggigil ruas-ruas tulangku dalam firmanMu

Isi makna yang terdapat dalam kalimat tersebut adalah bergetar sendi-sendi tulangku dalam mendengarkan dan mengkaji ayat-ayat seruan Allah.

Waammaa man tsaqulat mawaazienubu Fabuwa fi "iesyatir-raadliyah Waammaa man khaffat mawazienubu faummubu haawiyah Wamaa adraaka maa hiyah Naarun baamiyah (Nah barangsiapa berbobot timbangan amalnya Ia akan berada dalam kehidupan memuaskan Dan barangsiapa enteng timbangan amalnya Tempat tinggalnya di Hawiyah Tahukah kamu apa itu? Api yang sangat panas membakar!) Ya Tuhan, kemana gerakan belalang malang ini 'kan terlempar?

Isi makna kalimat diatas adalah barangsiapa manusia yang beratnya lebih kepada kebaikan pada saat di perhitungkan amalnya, ia akan mengalami kehidupan yang bahagia. Barangsiapa manusia yang ukuran perbuatan baiknya hanya sedikit, maka akan ditempat di neraka Hawiyah.

Tahukah apa itu neraka hawiyah? Neraka Hawiayah adalah sebuah tempat dengan api yang sangat-sangatlah panas. manusia akan bertanya-tanya akan kemanakah dia akan termasuk? Gunung amal yang dibanggakan Jadikan selembar bulu saja memberati timbangan Atau gunung-gunung dosa akan melumatnya Bagi persembahan lidah Hawiyah

Ataukah, o, kalau saja maharahmatMu Akan menebarbangkannya ke lautan ampunan 
Yang mempunyai makna bahwa tumpukan amal perbuatan yang telah di kerjakan semoga bisa dijadikan sekecil saja untuk memberati timbangan amal perbuatan. Apakah perbuatan besar bagai gunung itu akan memasukan ke dalam neraka Hawiyah. kalau saja kasih sayang Allah, akan menjadikan dosanya diampunkan, maka tidak bertanya-tanya, semoga saja ada rahmatmu.

Shadaqallahul'Adhiem Telah selesai ayat-ayat dibaca Telah sirna gema-gema sari tilawahnya Marilah kita ikuti acara selanjutnya

Masih banyak urusan dunia yang belum selesai Masih banyak kepentingah yang belum tercapai Masih banyak keinginan yang belum tergapai Marulah kembali berlupa Insya Allah Kiamat masih lama. Amien.

Telah selesai pengajian atau tadarus hari ini, telah selesai pula ayat-ayat yang telah dibaca dan telah selesai pula terjemahan dari ayat-ayat al-quran di terangkan dan mari kita kuti acara selanjutnya, masih banyak urusan dunia yang harus kita kaji ulang agar lebih baik di kemudian hari, agar tidak merasakan apa itu hari kiamat. Dan Insya Allah kiamat masih lama. Aamiin.( A. Mustofa Bisri, 2003: 4448).

\section{Puisi 2, DZIKIR 1}

biar angin mengirim badai, biar kilat mengirim halilintar, biar demit mengirim bangkai, biar iblis mengirim makar

Kalimat diatas memiliki isi makna yang sedang berandai andai jika angin mengirim badainya yakni sekencang-kencangnya angin ya biarlah, jika kilat mengirimkan halilintarnya ya biarlah, jika demit mengirimkan bangkai ya biarlah, jika iblis mengirimkan makar, ya biarlah. Dia akan tetap apada pendirian yang akan dilakukannya.

aku terus berdzikir bersama burung-burung dalam sangkar aku berdzikir jahri ya ya ya bersama rumput-rumput yang terinjak aku berdzikir khafi tidak tidak-tidak aku terus berdzikir biar sepi mengirim senyap biar nafsu mengirim syahwat biar lena mengirim lelap biar angkara mengirim laknat.

Kalimat diatas memiliki isi makna yang sedang berandai andai jika sepi mengirimkan senyap ya biar, jika nafsu mengirim syahwat ya biarlah, jika lena mengirim lelapnya ya biarlah, jika angkara mengirimkan laknat ya biarlah, ia akan tetap melakukan dzikir.

aku terus berdzikir bersama dedaunan yang tercampak aku berdzikir siapa pak siap pak siap pak bersama bebatuan yang terlempar aku berdzikir akhfa munkar munkar munkar

Kalimat diatas memiliki isi makna bahwa ia akan berdzikir dengan keadaan apapun.

aku terus berdzikir entah sampai kapan bersamamu.

Kalimat diatas memiliki isi makna bahwa ia akan teap melakukan dzikir sampai batas waktu yang tidak ditentukan. (1412/1992) (Mustofa Bisri, 2003:17)

Puisi 3, Puisi Islam

Islam agamaku, nomor satu di dunia

Kalimat ini memiliki sebuah isi makna bahwa islam adalah agama yang tidak 
ada tandingannya di dunia.

Islam benderaku, berkibar dimana-mana

Isi makna yang terdapat dalam kalimat tersebut ialah islam diibaratkan dengan bendera bahwa yang bisa berkibar dimana-mana, intinya islam merupakan agama yang termasyhur.

Islam tempat ibadahku, mewah bagi istana

Isi makna yang terdapat dalam kalimat tersebut ialah islam mengajarkan tentang beribadah yakni untuk mendekatkan diri kepada Allah dengan menjalankan perintahnya dan menjauhi larangannya. Ibadah dalam istana diartikan ibadah denganindah, nyaman dan terhormat.

Islam tempat sekolahku, tak kalah dengan lainnya

Isi makna yang terdapat dalam kalimat tersebut bahwa islam merupakan agama untuk menuntut ilmu yang ilmunya tidak kalah dari yang lain.

Islam sorbanku, Islam sajadahku, Islam kitabku

Isi makna yang terdapat dalam kalimat tersebut bahwa islam merupakan agama dengan menjungjung tinggi kehormatan, islam pun tempat pengampunan dan tempat bersyukur, dan islam merupakan pedoman bagi kehidupan.

Islam podiumku, kelas eksklusif yang mengubah cara dunia Memandangku tempat aku menusuk kanan-kiri

Isi makna yang terdapat dalam kalimat tersebut bahwa islam merupakan tempat besyiar yang mengubah pandanang manusa terhadap seorang manusia.

Islam media-massaku, gaya komunikasi islami masa kini. Tempat aku menikam sana-sini

Isi makna yang terdapat dalam kalimat tersebut, memaknai bahwa islam adalah media atau wadah dalam bersyiar pada masa ini dengan gaya berkomunikasi sesuai dengan perkembangan zaman yang pesat.

Islam organisasiku, Islam perusahaanku, Islam yayasanku

Isi makna yang terdapat dalam kalimat tersebut mengatakan bahwa islam adalah suatu wadah untuk pergrtsksn untuk melakukan banyak kajian, pelajaran dan mengekspresikannya dengan berpendapat dalam suatu wadah organisasi, atau dalam menjalankan sebuah perusahaan, dan uga tempat dimana kumpul dalam sebuah majlis.

Islam instansiku, menara dengan seribu pengeras suara

Makna yang terdapatdalam kalimat diatas yakni islam merupakan rumah yang dengan banyaknya orang yang bersyiar.

Islam muktamarku, forum hiruk-pikuk tiada tara

Isi makna yang terdapat dalam kalimat diatas yakni islam merupakan konferensiku, tempat dimana terjadi forum berdiskusi tiada henti.

Islam bursaku

Isi makna yang terdapat dalam kalimat tersebut yakni islam menjadi pembicaraanku karena dengan kita menggali Islam kita akan mencapai islam yang sebenarnya.

Islam warungku, hanya dengan seribu pengeras suara

Isi makna yang terdapat dalam kalimat tersebut ialah islam merupakan 
tempat mempelajari berbagai macam hal yang bermanfaat tentang suatu kebenaran akan menuju sampai surganya.

Islam supermarketku, melayani segala keperluan manusiawi

Isi makna yang terdapat dalam kalimat tersebut mengatakan bahwa islam merupakan tempat untuk melayani segala yang diperlukan oleh umat.

Islam makananku, Islam teaterku, menampilkan karakter-karakter suci, Islam festivalku, memeriahkan hari-hari mati

Kalimat ini memiliki sebuah makna, dimana islam merupakan sebuah hal yang tidak bisa dimerngerti karena bisa diibaratkan dengan teater yang dimana disana menampilkan tentang berperan dengan karakter yang suci atau islami

Islam kausku Islam pentasku Islam seminarku, membahas semua Islam upacaraku, menyambut segala Islam puisiku, menyanyikan apa Tuhan, Islamkah aku?

Kalimat ini memiliki sebuah isi makna yakni ia bertanya-tanya apakah aku bisa dianggap dan bisa disebut sebagai agama islam. (1413/1993) (Mustofa Bisri, 2003: 29-30).

\section{Puisi 4, TAKZIAH}

Langit, mengapa ikut menangis?

Kalimat ini memiliki sebuah isi makna yakni aku melihat langit ikut menangis, maksudnya adalah langit menurunkan air hujan dan seakan-akan ia iku merasakan larut dalam kesedihan. begini?

tidak cukupkah ribuan pasang mata disini membobol bendungan airmata

Isi makna yang terdapat dalam kalimat tersebut adalah beribu orang yang hadir dan berkaca-kaca melihat peristiwa yang terjadi.

dan, ayah mengapa kau malah tersenyum sendiri?

Kalimat ini mempunya isi makna bahwa mengapa ayah malah tersenyum sendiri, tidak merasakan kesedihan yang dirasakn orang lain karena kehilanganmu.

ayah, apa yang dikatakan malikat rahmat kepadmu? ayah, katakan sesuatu kau melihat apa? bicaralah seperti biasanya!

Isi makna yang terdapat dalam kalimat diatas yakni, seorang anak bertanya kepada ayahnya sedang melihat apakah ayaknya dan dia ia ingin mengetahui, bahkan memaksa untuk diberikan jawaban.

ini umatmu sudah berkumpul dari segala penjuru

Kalimat ini memiliki sebuah isi makna bahwa sahabat, keluarga,bahkan murid, telah berkumpul dari berbagai tempat. Kangen merdu-suaramu membaca ayat-ayat suci rindung mendengar kelakar-segarmu ingin menyimak fatwasejukmu yang menentramkan hati langit,

Kalimat ini memiliki sebuah isi makna menyampaikan sangat ingin mendengar suara lantunan ayat suci dan dindu pula mendengar ceramah-ceramah yang menyejukan dan menentramkan hati. kan baru beberapa hari yang lalu dia memukau jemaahnya dengan sajak mutiara yang dibacanya

"bila hari ini kau memikul keranda jangan lupa, suatu ketika kau pasti ganti dipukul 
pula bila suatu saat kau diberi amanat atas umat ingat, pada gilirannya kau pun pasti brenti atau dipecat"

Kalimat ini memiliki sebuah isi makna bahwa menyatakan baru saja harihari yang lalu, ayahnya mempesaona jamaah atau pendengarnya dalam sebuah sajak yang berisi bahwa "apabila hari ini kau memikul keranda jangan lupa suatu ketika kau pasti akan dipikul pula dan biala suatu saat kau diberi amanat oleh umat ingat, pada gilirannya kau pasti akan berhenti atau dipecat".

rupanya kau, ayah sudah mencoba memberi alamat kami saja yang tak dapat menangkap isyarat.

Kalimat ini memiliki sebuah isi makna bahwa ayah sudah memberi tahukan tanda-tanda bahwa ia akan meninggalkan dunia ini dengan isyarat sajak tadi, namun isyarat itu tidak dapat ditangkap oleh orang-orang di sekitarnya.

ayah karena itu pulakah kau kini tersenyum damai sekali karena yang memberimu telah menjemputmu kembali?

Kalimat ini memiliki sebuah isi makna yang dimana bahwa ia mengerti kenapa ayahnya sudah tiada, dikarenakan ynag telah memberikan umur hidup di duia yakni Allah SW'T telah mengambilnya karena sayangnya Allah kepada beliau. (1396/1977) (Mustofa Bisri, 2003:36).

Puisi 5, Selamat Idul Fitri

selamat idul fitri, bumi maafkanlah kami selama ini tidak semena-mena kami memerkosamu

Kalimat ini memiliki sebuah isi makna yaitu, sekelompok manusia atau sekelomok rakyat mengungkapkan penyesalannya atas apa yang telah diperbuat, seperti telah menanfaatkan sumber dayanya tapi tidak melestarikannya.

selamat idul fitri, langit maafkan kami selma ini tidak henti-hentinya kami mengelabukanmu

Kalimat ini memiliki sebuah isi makna yaitu, sekelompok manusia atau sekelomok rakyat mengungkapkan penyesalannya kepada langit atas apa yang telah diperbuat, seperti tidak henti-hentinya kami membohongi dan menjadi atap bagi rumah kami.

selamat idul fitri, mentari maafkan kami selma ini tidak segan-segan kami mengeruhkanmu

Kalimat ini memiliki sebuah isi makna yaitu, sekelompok manusia atau sekelomok rakyat mengungkapkan penyesalannya atas apa yang telah diperbuat, seperti yang tidak memperdulikan dan mengacuhkan fungsi dari mentari sendiri padahal manfaat sinarnya itu sangat dahsyat.

selamat idul fitri, laut maafkan kami tidak bosan-bosan kami mengaburkanmu

Kalimat ini memiliki sebuah isi makna yaitu, sekelompok manusia atau sekelomok rakyat mengungkapkan penyesalannya atas apa yang telah diperbuat, seperti kami sebagai sekelompok manusia telah menggunakan laut hingga mengkeruhkannya untuk kebutuhan hidup.

selamat idul fitri, burung-burung maafkan kami selama ini tidak putus-putus kami membrangusmu 
Kalimat ini memiliki sebuah isi makna yaitu, sekelompok manusia atau sekelomok rakyat mengungkapkan penyesalannya atas apa yang telah diperbuat, seperti telah membunuh bukan merawat, semua ini di karenakan manusia.

selamat idul fitri tumbuhan maafkan kami selama initidak puas-puas kami menebasmu

Kalimat ini memiliki sebuah isi makna yaitu, sekelompok manusia atau sekelomok rakyat mengungkapkan penyesalannya atas apa yang telah diperbuat, seperti banyak manusia yang telah menebang liar bukan merawat dan melestarikan tumbuhan.

selamat idul fitri, para pemimpin maafkan kami selama ini tidak habis-habis kami membiarkanmu

Kalimat ini memiliki sebuah isi makna yaitu, sekelompok manusia atau sekelomok rakyat mengungkapkan penyesalannya atas apa yang telah diperbuat, seperti telah membiarkan seorang pemimpin yang sudah semena-mena dan memanfaatkan rakyatnya untuk kepentingannya pribadi.

selamat idul fitri, rakyat maafkan kami selama ini tidak sudah-sudah kami mempergunakanmu

Kalimat ini memiliki sebuah isi makna yaitu, sekelompok manusia atau sekelomok rakyat mengungkapkan penyesalannya atas apa yang telah diperbuat, seperti telah mempergunakan tenaga rakyat dan tidak ada balasannya. (Mustofa Bisri, 2003: 55-56).

Puisi 1, hal 44-48. Puisi yang berjudul "Tadarus" ini diawali dengan kalimat:

Bismillaabirrahmaanirrabiem, Berhenti darahku menyimak firmanMu

Mengartikan bahwa darah yang mengalir dalam diri ini berhenti sejak mendengarkan, memperhatikan baik-baik apa yang di ucapkan serta memeriksa atau mempelajari dengan teliti tentang seruan-seruan $\mathrm{Mu}$ (Allah). Seruan atau firman merupakan sebuah ajaran ajakan sebuah pesan-pesan yang disampaikan oleh Allah SW'T.

Pesan-pesan yang diserukan oleh Allah SWT berada dalam firman-Nya dalam Al-Qur'an surat Al-Zalzalah, ayat 1-8. Menjelaskan tentang bagaimana keadaan saat hari kiamat tiba. Bumi akan digoncangkan dan meruntuhkan segala yang ada di bumi. Baik dan buruknya sebuah perbuatan yang kita lakukan akan dibalas pada hari tersebut sesuai dengan apa yang telah kita perbuat. Tidak hanya dalam surat al-zalzalah saja, namun dalam surat Al-Adiyat ayat 1-11, dan AlQari'ah 1-11.

Dalam puisi tadarus ini, kita mengkaji berbagai hal tentang hari kiamat yang akan tiba pada suatu hari, dan dijelaskan bahwa keadaan yang akan kita alami pada saat hari itu akan terjadi, hingga kita dikumpulkan di padang mahsyar akan diminta pertanggung jawaban amal perbuatan, apakah akan berat kepada perbuatan baik atau malah berat kepada perbuatan yang buruk, itu semua tergantung dengan amal perbuatan yang kita lakukan di dunia.

Puisi tadarus ini memiliki sebuah pesan dakwah dengan mengkaji dan mempelajari Al-Qur'an, yang mana dengan adanya ayat tersebut, dapat kita 
simpulkan bahwa hari kiamat akan datang, namun entah kapan waktu terjadinya, itu adalah rahasia Allah SWT. Peristiwa kiamat merupakan sebuah bentuk pesan aqidah, karena mengkaji dan mempelajari tentang iman kepada hari akhir, karena adanya bisa kita yakini ada.

Puisi 2, hal 17. Puisi yang berjudul "Dzikir 1" di dalam puisi ini mengandung ajakan untuk selalu mengingat Allah dengan cara berdzikir walau dalam keadaan apaun. Berdzikir merupakan suatu yang bernilaikan ibadah. Karena berdzikir bisa membuat manusia mendekat kepada Tuhan. Jika kita dekat dengan Tuhan niscaya, Tuhan akan membalas mendekat kepada kita serta melindungi dari segala kemungkaran yang ada. puisi dzikir ini menggunakan kata aku sebagai orang yang sedang ada dalam keadan yang bertawadhu kepada Tuhan, bahwa dia hanya dapat disamakan dengan burung-burung dalam sangkar, dedaunan yang tercampak, karena begitu tetaplah berdzikir dan sampai kapanpun ia tetap berdzikir. Manusia tidak lukut dari kesalahan dengan berdzikirlah kita bisa bersyukur dengan yang ada, tidak melihat keatas, namun terlebig bertawadhu agar dapat mendapatkan rahmat Tuhan yang Maha Pengasih.

Puisi 3, hal 18. Puis yang berjudul "Puisi Islam". Puisi dengan judul puisi islam ini, mempunyai makna yang sangat kaya. Islam nomor satu agama di dunia menurut aku (ku). Islam pun merupakan bendera, yang berada diatas, di junjung tinggi, di hormati dan dihargai yang bisa terkibar dalam langit-langit yang tinggi karena saking menjungjung tinggi keislamannya dengan berkibar (dijunjung) dimana-mana (diartikan banyak). Islam merupakan ibadah, yakni menunaikan perintah kepada Allah dengan ketaatan, mengerjakan seluruh perintah Allah dan menjauhi segala larangan Allah SWT.

Puisi islam ini menanyakan apakah kita sebagai umat yang mengaku Islam bahkan mengucapkan kata bahwa saya adalah Islam, sudah benarkah Islam kita? Atau malah sebaliknya oleh karena itu puisi ini mempertanyakan benar-benar islam atau tidakkah kita. Puisi ini mempunyai pesan Ibadah, yang menanyakan tentang keislaman dari seseorang, dan ada dalam rukun iman.

Puisi 4, hal 36, yang berjudul "Takziah". Puisi ini merangkan sebuah keadaan yang dimana seseorang yang meninggal dengan keadaan yang sangat haru seakan langit ikut menangis, mengerti terjadinya suatu keadaan yang sedang sedih. Banyak orang yang hadir disana dengan menagisi, karena tidak dapat percaya bisa ditinggalkan secepat itu. Pesan yang disampaikan puisi ini, bahwa seluruh orang akan mengalami kematian, sekrang bisa memikul dan mengiringi pada kematian seseorang, namun nanti kita yang mengiringinya akan menjadi orang yang akan di pikiul dan diiringi, diantar kepada rumah yang sebenarnya yakni alam akhirat. Setiap manusia tidak akan ada yang kekal di dunia, mereka akan kembali kepada sang khalik.

Isi pesan yang terkandung dalam puisi ini adalah pesan ibadah yang mana kita sebagai manusia akan kembali kepada Allah. Selain pesan ibadah terdapat pula pesan Akhlak yang mana dalam puisi ini, kita sebagai manusia yang bersifat manusiawi sudah sepantasnya bertakziah, menjenguk orang yang meninggal dan mengatakan bela sungkawa terhadap keluarga. 
Puisi 5, hal 55. Puisi dengan judul "Selamat Idul Fitri” ini merupakan salah satu karya Gus Mus, yang kaya dengan makna. Selamat idul fitri merupakan sebuah ucapan dengan kata selamat atas datangnya hari atau waktu kepada hari yang suc. Dimana setiap manusia yang memegang agama islam, bermaaf-maafan atas segala ksesalahan yang telah diperbuatnya. Dalam bait pertama tertulis dalam syair, yaitu sebagai berikut:

selamat idul fitri, bumi maafkanlah kami selama ini tidak semena-mena kami memerkosamu

lirik di atas ada kata kami, yang mengandung arti kami itu adalah banyak berarti bukan satu orang melainkan dapat di artikan sekelompok manusia atau sekelompok rakyat yang meminta maaf kepada bumi karena kami telah memerkosamu, maksud lirik memerkosamu itu adalah karena tetah memanfaatkan alam tapi tidak melestarikannya atau telah mengambil sesuatu yang berharga di bumi untuk kebutuhan sehari hari.

Dalam bait-bait yang lainnya pun terdapat lirik atau kata kami dan maafkanlah. Kata maafkanlah mempunyai makna yang sama dengan lirik pertama yakni mengungkapkan penyesalannya. Siapa yang melakukan penyesalannya yaitu kata kami, yakni artinya sama seperti lirik pertama adalah sekumpulan manusia atau rakyat yang meminta serta memohon maaf kepada bumi, langit, mentari, laut, burung-burung, tumbuhan, para pemimpin, dan rakyat.

Meminta maaf terhadap bumi karena selama ini telah memanfaatkan bumi mengambil sesuatu yang berharga di bumi. Kepada langit yang sudah membohongi langit dengan terus-menerus yang telah menjadi atap tempat tinggal kami. Kepada mentari yang tidak memperdulikan dan mengacuhkan fungsi dari mentari sendiri, karena dengan sinarnya kita memiliki manfaat yang banyak. Kepada laut, meminta maaf karena kami sebagai sekelompok manusia telah menggunakan laut hingga mengkeruhkannya untuk kebutuhan hidup.

Kepada burung-burung, maafkanlah atas segala perbuatan manusia yang telah membunuh bukan merawat, semua ini di karenakan manusia dan kami meminta maaf. Kepada tumbuhan, meminta maaf karena banyak manusia yang telah menebang liar bukan merawat dan melestarikan tumbuhan agar bumi terlihat lebih indah dan nyaman karena kesegaran hijaunya yang nyaman dengan menghirupnya.

Kepada pemimpin, kami yakni manusia meminta maaf kepada diri sendiri karena telah membiarkan seorang pemimpin yang sudah semena-mena dan memanfaatkan rakyatnya untuk kepentingannya pribadi. Semua ini nyata adanya, Indonesia merupakan negri yang sudah tertinggaldari negara-negara lain karena ketamakan para pemimpin yang ego mengurus kehidupan pribadinya, sedangkan rakyat masih mengalami kemiskinan, kebodohan, kelapar, sedangkan penguasa mereka tamak, rakyatlah yang sengsara. Oleh karena itu kita mengalami ketertinggalan dan keterbelakangan dari negara-negara yang sudah maju akan rakyatnya.

Terakhir dalam kutipan puisi ini meminta maaf kepada rakyat karena kami 
disini mempunyai makna sebagai seorang pemimpin atau penguasa yang merasa akan kesalahannya. Kesalahan yang telah mengumbar kata-kata yang manis kepada rakyat yang belum bisa dicapai. kesalahan karena telah mempergunakan rakyat dengan semena-mena. Kesalahan degan mengambil hak rakyat, dan melakukan kebohongan kepada rakyat.

Isi pesan yang ada dalam puisi ini adalah pesan akhlak. Karena dalam puisi ini kita mendapatkan suatu perilaku kita sebagai sekelompok manusia agar bisa bijak mempergunakan alam dan seisinya yang ada di bumi. Dan selaku manusia kita mempunyai kesalahan, maka dari itu sepantasnya kita meminta maaf atas kesalah-kesalah yang telah di perbuat baik sengaja maupun yang tidak disengaja.

\section{Karakter Pesan Dakwah dalam Antologi Puisi Tadarus}

Pesan Dakwah memiliki sebuah ciri atau karakteristik yang berbeda, yakni mengandung sebuah unsur kebenaran, membawa pesan perdamaian,tidak bertentangan dengan nilai-nilai universal, memberikan kemudahan bagi penerima pesan,mengapresiasi adanya perbedaan (Basit, 2013: 142-146).

Karakteristik yang ada dalam Antologi Puisi Tadarus ini adalah Tadarus, memiliki sebuah karakter pesan yaitu: mengandung unsur kebenaran, membawa pesan damai, tidak bertentangan dengan nilai-nilai Universal. Dzikir 1, memiliki sebuha karakter pesan yaitu: mengandung unsur kebenaran, memberikan kemudahan bagi penerima pesan, tidak bertentangan dengan nilai-nilai universal, membawa pesan damai. Puisi Islam, memiliki sebuha karakter pesan yaitu: mengandung unsur kebenaran, tidak bertentangan dengan nilai-nilai universal, membawa pesan damai, memberikan kemudahan bagi penerima pesan. Takziah, memiliki sebuha karakter pesan yaitu: mengandung unsur kebenaran, memberikan kemudahan bagi penerima pesan, tidak bertentangan dengan nilai-nilai universal, membawa pesan damai.

\section{PENUTUP}

Berdasarkan hasil penelitian yang dilakukan mengenai pesan dakwah dalam puisi Gus Mus ini, dapat disimpulkan isi pesan dakwah yang terdapat dalam Antologi ini adalah sebagai berikut: Pesan-pesan Ibadah, dimana dalam puisi tersebut, setelah dianalisis maknanya terdapat kesimpulan bahwa didalamnya mengandung pesan-pesan ibadah. Karena dalam sebuah rangkaian kata perkata sehingga menjadi kalimat tersebut terdapat unsur mengajak kepada ajaran Allah. Yang dimana ajaran tersebut termasuk kepada ibadah.

Pesan-pesan Akhlaq, makna pusi-puisi tersebut mengajak untuk mengintropeksi diri agar lebih bisa memperbaiki diri. Bukan hanya kepada Allah bahkan kepada sesama makhluk.

Pesan-pesan Aqidah. Dalam Antologi Tadarus ini, pesan-pesan aqidah merupakan salah satu yang menjadi isi pesan yang terkandung dalam puisi tersebut. Puisi-puisi ini pun menggambarkan tentang sebuah keyakinan kepada Tuhan. Dimana dalam puisi-puisi tersebut terdapat salah satu puisi yang 
mempunyai makna mengajak untuk meyakini hal-hal keimanan.

Karakteristik pesan yang terdapat pada analisis puisi tadarus ini, adalah sebagai berikut: 1) Mengandung Unsur Kebenaran. Di dalam sebuah puisi-puisi yang terdapat dalam antologi ini, telah terbukti bahwa karakteristik pesan yang terdapat salah satunya adalah mengandung unsur kebenaran. Karena puisi-puisi tersebut bersifat benar sesuai dengan apa yang dirasakan di masyarakat, sehingga dapat dimengerti oleh para pembacanya. 2) Membawa Pesan Perdamaian. Dalam puisi tadarus ini membawa pesan perdamaian. Karena dalam sebuah maknanya tidak ada yang mengandung unsur-unsur permaslahan yang memicu akan perpecahan. 3) Tidak Bertentangan dengan Nilai-Nilai Universal. Puisi tadarus antologi ini, mempunyai sebuah karakteristik yang tidak bertentangan dengan nilai-nilai universal. Karena pengarang mempunyai nilai atau segi pemahaman yang tidak akan mengganggu pemahaman dari orang lain. 4) Memberikan Kemudahan bagi Penerima Pesan. Antologi puisi Tadarus ini, mempunyai salah satu karakteristik yang dimana memberikan sebuah kemudahan bagi penerima pesan. Bisa dikatakan setelah ditelaah makna dalam puisi-puisi yang ada dalam antologi ini bahsanya sangat mudah di pahami bagi para pembacanya, karena merupakan bahasa yang sederhana.

\section{DAFTAR PUSTAKA}

Kafi, Jamaludin. (1997). Psikologi Dakwah. Surabaya: Indah.

Syukir, Asmuni. (1983). Dasar-Dasar Strategi Dakwah Islam. Surabaya: Al Ikhlas.

Aziz, Moh. Ali. (2014). Ilmu Dakwah Edisi Revisi. Jakarta: Kencana.

Basit, Abdul. (2013). Filsafat Dakwah. Jakarta: PT. Raja Grafindo Persada.

Sopandi. (2010). Memahami Puisi. Bogor: Quadra.

Pradopo, Rahmat Djoko. (2014). Pengkajian Puisi. Yogyakarta.

Teeuw, A. (1980). Tergantung Pada Kata. Jakarta: J.B. Wolters.

Perrine, Laurence. (1974). Literature: Structure, Sound and Sence. Nem York: Harcourt Brace Jovanovich, Inc.

Syukir, Asmuni. (1983). Dasar-Dasar Strategi Dakwah Islam. Surabaya: Al Ikhlas.

Aziz, Moh Ali. (2004). Ilmu Dakwah. Jakarta : Kencana.

Munir, Muhammad. Ilaihi, Wahyu. (2009). Menejemen Dakwah. Jakarta: Kencana.

Ahmed, Salahudin. A. (1993). Posmodernisme: Bahaya dan Harapan bagi Islam, Bandung: Mizan.

Hanafi, Hasan. (2001). Agama Kekerasan, dan Islam Kontenporer. Yogyakarta: Jendela. Widjaja, W. A (1993). Komunikasi (Komunikasi dan Hubungan Masyarakat). Jakarta: Bumi Akasara.

Basit, Abdul. (2013). Filsafat Dakwah. Jakarta: PT. Raja Grafindo Persada.

Saputra, Wahidin (2012). Pengantar Ilmu Dakwah. Jakarta: Raja Grafindo Persada. Bisri, A. Mustofa. (2003) Tadarus Antologi Puisi. Yogyakarta: Adicitya Karya Nusa. Tajiri, Hajir. (2016). Pemikiran Dakwah Endang Saefudin Anshori dalam Imu Dakwah: Academic Journal for Homiletic Studies,1(2), 700-728. 